\title{
CIÊNCIANATURA
}

\section{State of Art of Landfill Leachate Treatment: Literature Review and Critical Evaluation}

\author{
O Estado da Arte do Tratamento do Lixiviado de Aterros Sanitários: Revisão Bibliográfica e \\ Avaliação Crítica
}

\author{
Marcelo Lippi ${ }^{1}$, Michelle Bellas Romariz Gaudie Ley², Gabriel Pinna Mendez ${ }^{3}$ e \\ Ricardo Abranches Felix Cardoso Junior ${ }^{4}$ \\ 1,2,4 Universidade Federal Fluminense, RJ, Brasil \\ ${ }^{3}$ Centro Federal de Educação Tecnológica Celso Suckow da Fonseca, RJ, Brasil
}

\begin{abstract}
Population growth, especially in urban areas, combined with modern levels of social consumption, contribute for a significant increase of waste production. Among the environmental impacts resulting from the operation of landfills, the generation of leachate is certainly one of the most significant and most difficult to control. The composition of leachate is complex and varied; it contains physicochemical and biological characteristics that are aggressive to the soil, water resources, fauna and flora. The technical and operational difficulties to handle it are challenges for waste managers. There are several methods to treat leachate, which are widely debated in the literature, each having advantages and disadvantages. The present paper has the objective of carrying out a bibliographical review of leachate treatment from landfills, addressing the main technologies, as well as discussing their applications, advantages, disadvantages and uncertainties. According to what was studied, the technologies that have been found to have the best practical results and, in general, reach the parameters for treated effluent provided for environmental legislations, are those that use filtering membranes. However, one of the major disadvantages of these processes is the generation of a concentrate, which is normally recirculated in the landfill itself.
\end{abstract}

Keywords: Leachate treatment; Landfills; Solid waste management 
Each year, 1.3 billion tons of Municipal Solid Waste (MSW) are produced on the planet, with a value of 2.2 billion projected for 2025 (SHAH et al., 2017). According to Kamaruddin et al. (2017), the current global scenario indicates that $94.5 \%$ of MSW is directed towards landfills. In Brazil, according to ABRELPE (2018), 78 million tons were produced in 2017 and only $59,1 \%$ were intended to landfills. Therefore, it is important to understand that one of the main environmental impacts of MSW disposal are the leachates (TALALAJ, 2015). This liquid without proper control has a negative and direct effect over the environment, reaching soil and water resources, the economy and society are also affected. It compromises the social aspects such as public health and water security (DI MARIA and. SISANI, 2017).

The generation of leachate occurs due to biodegradation of MSW provided by anaerobic and/or aerobic microorganism combined with residues characteristics and precipitation (FRANCO et al.; 2017). It is important to elucidate that organic and inorganic recycling process reduce the amount of leachate produced due to the deviation of litter from landfills. Leachate has a dark color and contains inorganic salts, possibly heavy metals, ammoniacal nitrogen and refractory and biodegradable organic matter (FERRAZ et al., 2016). Its composition has a vast physicochemical and biological variability, depending on factors such as residues type, clime, hydrology and landfill physical characteristics. Due to leachate high pollution potential, environmental control agencies were pressured by society to implement more rigid leachate discharge parameters (RAGAZZI, 2016).

Therefore, the aim of this article is to present a bibliographical review addressing the different leachate treatment techno-

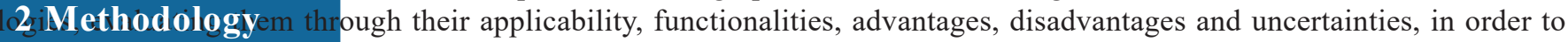
provide a better view of this scenario and help the correct choice of leachate treatment.

The state of the art of the landfill leachate treatment was carried out by searching technical and academic references, such as: scientific articles, international conference papers and company's technical documents. The documents were obtained utilizing the databases Scopus and Science Direct, applying the key words: leachate, leachate treatment, membranes treatments and landfills. Consultations with professionals of the area were also made. Furthermore, the Mendeley platform was used to manage and discover bibliographic data.

The documents published in the last five years were prioritized, but the former relevant ones were not discarded. The documents selected, in addition to describe landfills leachate treatment techniques, had empirical results regarding operation as well as advantages and disadvantages of the systems. Thereby, comparative analyzes could be made between the various methods and techniques.

So as to comprehend the advances on research and development of leachate treatment, a bibliometric survey was necessary. Therefore, to understand the future of science, technology, economy and society on the leachate treatment field, figure 1

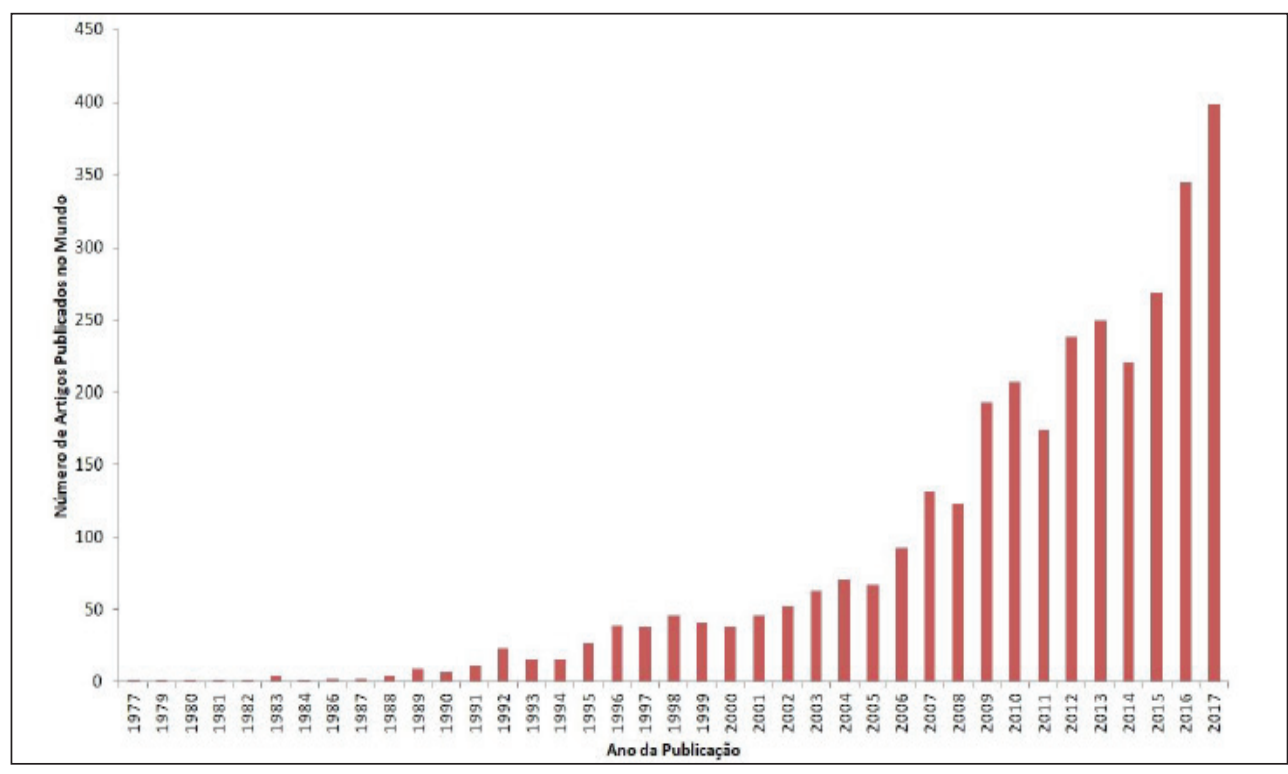

Source: (M. Santos, A. Nascentes, A. Junior et al., 2018) 
demonstrates the advances made over the years.

Figure 1 - International publication by year about leachate treatment from landfills

\subsection{Technology Selection}

The choice of the best treatment technology for an specific leachate covers several aspects: flow generation and physicochemical composition of the leachate, available area for the system plant, investment capacity and operation of the landfill (CAPEX / OPEX) and compliance with the norms and laws established by the local environmental agency (BIDONE, 2007).

According to Renou et al. (2008), treatment technologies can be divided into three classes: recirculation at the landfill, biodegradation, and physicochemical methods (which contains the membrane methods). However, membrane technologies require a preliminary chemical treatment, followed by a physical treatment provided by membranes, thus differing from traditional physicochemical processes. For this reason, although the previous classification is currently the most used, the present study considered it pertinent to classify the leachate treatment methods in four thematic axes, namely: biological, physicochemical, co-treatment with domestic sewage and membranes; as shown in figure 2.

Figure 2 - Classification of leachate treatment methods

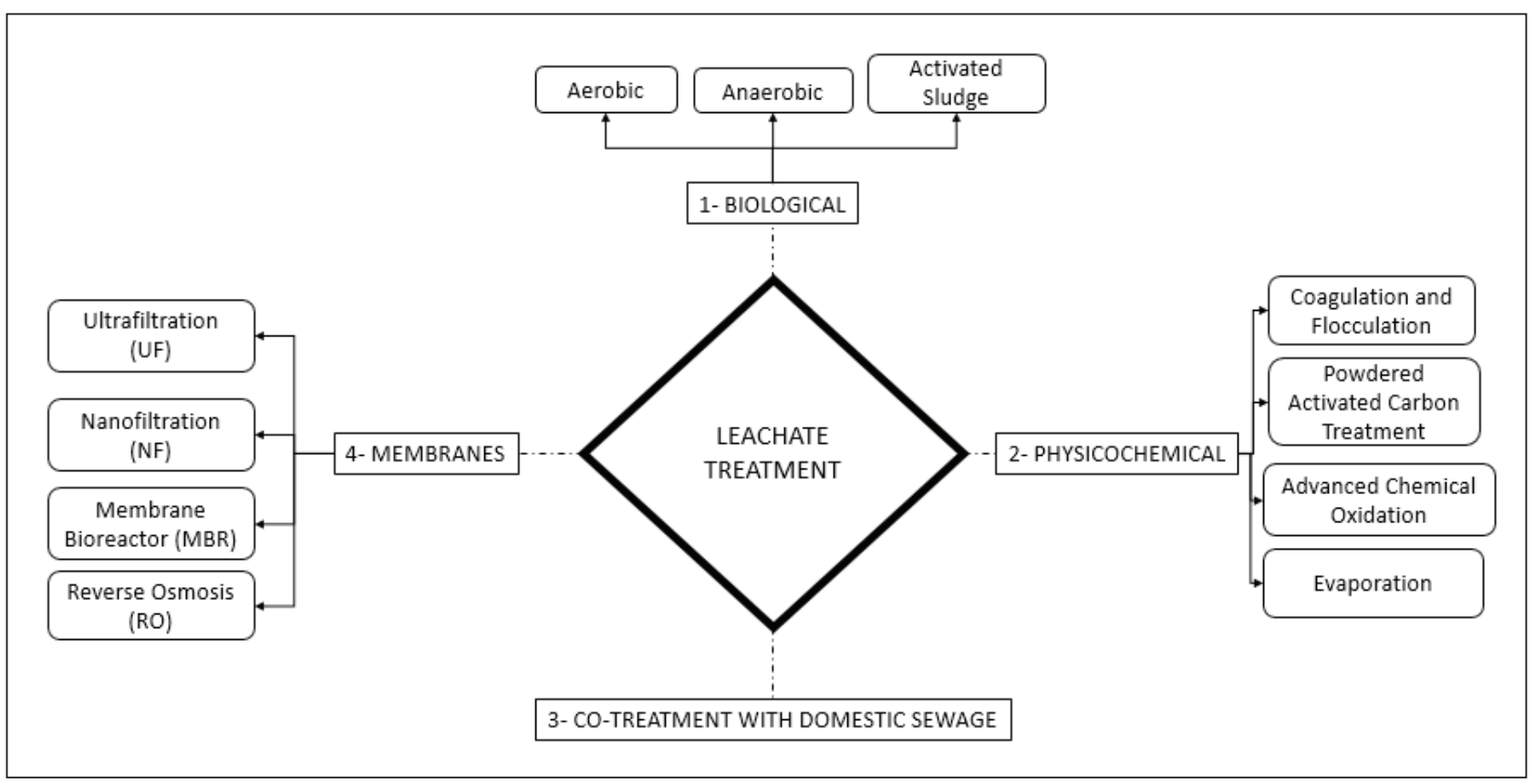

Source: Authors elaboration

\subsection{Technologies for Leachate Treatment}

\subsubsection{Biological Treatments}

Biological treatments are used for biodegradation of organic compounds, especially in leachates with high concentration of Biochemical Oxygen Demand (BOD), due to the relative simplicity and cost-effectiveness associated to it. These techniques promote, through the decomposing activity of microorganisms, transformation of the compounds present in leachate on: carbonic gas and biomass at sludge form, when submitted to aerobic conditions; and biogas, when submitted to anaerobic conditions. This type of treatment is advised and is efficient for new immature leachates, where the ratio of Biochemical and Chemical Oxygen Demands (BOD / COD) are greater than 0.5 (PENG, 2013). However, these types of treatments have operational sensitivity and tend to have its efficiency affected by the physicochemical and biological variability of the leachate. Likewise, another worrisome factor, when placed alone, this technology doesn't remove recalcitrant substances, such as refractory organic matter and drugs. Table 1 summarizes the advantages and disadvantages of applying biological treatments for leachate remediation". 
Table 1 - Advantages and disadvantages of biological treatment systems for leachate

\begin{tabular}{|c|c|c|c|c|}
\hline & System Type & Advantages & Disadvantages & Observations \\
\hline $\begin{array}{l}\text { Biological treatment } \\
\text { under aerobic conditions }\end{array}$ & Air Stripping & $\begin{array}{c}90 \% \text { removal of COD } \\
\text { and ammoniacal nitrogen }\end{array}$ & $\begin{array}{l}\text { It is not always that it } \\
\text { shows good results due } \\
\text { to the } \\
\text { large periods of } \\
\text { hydraulic detention and } \\
\text { high costs (CAPEX / } \\
\text { OPEX) }\end{array}$ & $\begin{array}{l}\text { It is worth highlighting } \\
\text { the difficulty of } \\
\text { solubilizing the oxygen } \\
\text { in the leachate, and it } \\
\text { may be necessary to } \\
\text { acquire a condensator to } \\
\text { optimize the process. In } \\
\text { addition, is advised the } \\
\text { insertion of phosphoric } \\
\text { acid (H3PO4) in a ratio } \\
\text { of } 1: 100 \text { of the BOD } \\
\text { concentration }\end{array}$ \\
\hline $\begin{array}{l}\text { Biological treatment } \\
\text { under anaerobic } \\
\text { conditions }\end{array}$ & $\begin{array}{c}\text { Stirred tank } \\
\text { Anaerobic filter } \\
\text { UASB } \\
\text { Movie bed } \\
\text { Fixed bed }\end{array}$ & $\begin{array}{l}\text { Simple techniques; low } \\
\text { cost; reduced hydraulic } \\
\text { holding times; low } \\
\text { sludge generation; } \\
\text { ability to receive high } \\
\text { concentrations of organic } \\
\text { components }\end{array}$ & $\begin{array}{l}\text { Temperature factor, } \\
\text { requiring heating or } \\
\text { cooling. The toxicity } \\
\text { of leachate, especially } \\
\text { that of ammonia, may } \\
\text { represent a danger to } \\
\text { the microbiological } \\
\text { fauna responsible for } \\
\text { anaerobic degradation. } \\
\text { Low efficiency }\end{array}$ & $\begin{array}{l}\text { It is worth mentioning } \\
\text { the possibility of using } \\
\text { biogas, generated at the } \\
\text { landfills as an energy } \\
\text { source, to maintain the } \\
\text { desirable temperature }\end{array}$ \\
\hline Activated Sludge & $\begin{array}{l}\text { Conventional } \\
\text { System }\end{array}$ & $\begin{array}{c}\text { Efficiency removal } \\
\text { of BOD5 and COD } \\
\text { between } 90 \text { and } 99 \% \text {; } \\
\text { metal removal efficiency } \\
\text { between } 80 \text { and } 99 \%\end{array}$ & $\begin{array}{l}\text { High costs (CAPEX / } \\
\text { OPEX); low efficiency } \\
\text { in fecal coliform } \\
\text { removal; sensitive } \\
\text { to certain toxicities; } \\
\text { disposal of the final } \\
\text { sludge; possible } \\
\text { environmental problems } \\
\text { with aerosols and noise }\end{array}$ & $\begin{array}{l}\text { This technology consists } \\
\text { of three modules: } \\
\text { an aerobic reactor, a } \\
\text { sedimentation tank } \\
\text { separating the liquid } \\
\text { and solid material, and a } \\
\text { recirculation system of } \\
\text { the sludge generated in } \\
\text { the settlers }\end{array}$ \\
\hline
\end{tabular}

Source: Compilations of fonts adapted from (CAMPOS, 2014; NASCENTES, 2013; SANTOS, 2009; RENOU et al. ,2008)

\subsection{Physicochemical Treatments}

Physicochemical processes originated of the need to improve the efficiency of biological treatment systems. Thus, they are generally used downstream of a biological pre-treatment. This system acts by modifying the chemical structures of specific pollutants, or physical elements with capacity to retain or eliminate pollutants. Furthermore, the process choice is specific, being directly related to the parameters to be reached on (COSTA, 2015). Some advantages and disadvantages of these technologies are on Some advantages and disadvantages of these technologies are on Table 2. 
Table 2 - Advantages and disadvantages of leachate physicochemical treatment systems

\begin{tabular}{|c|c|c|c|}
\hline Physicochemical & Advantages & Disadvantages & Observations \\
\hline Coagulation and Flocculation & $\begin{array}{l}\text { Efficient in removal of humic } \\
\text { acids, heavy metals, suspended } \\
\text { solids and organic matter }\end{array}$ & $\begin{array}{l}\text { The coagulants concentrations } \\
\text { are required for the system } \\
\text { operation are very high, turning it } \\
\text { economically unfeasible to apply } \\
\text { this technology in a real scale } \\
\text { due to the costs of inputs and the } \\
\text { management of chemical sludge } \\
\text { generated }\end{array}$ & $\begin{array}{l}\text { This technology appears } \\
\text { as pre-treatment for } \\
\text { some membrane } \\
\text { systems }\end{array}$ \\
\hline $\begin{array}{l}\text { PACT (Powdered Activated } \\
\text { Carbon Treatment) }\end{array}$ & $\begin{array}{l}\text { Removes color, odor, taste, COD, } \\
\text { chlorine, phenols, ammoniacal } \\
\text { nitrogen and some toxins. Sta- } \\
\text { bilizes and protects the process } \\
\text { against shock loads of BOD and } \\
\text { organic toxins. It has low in- } \\
\text { stallation costs, easy operation } \\
\text { and maintenance. Technology } \\
\text { appears as pre-treatment for } \\
\text { some membrane systems }\end{array}$ & $\begin{array}{l}\text { High operational costs with re- } \\
\text { placement of coal or on-site re- } \\
\text { generation and outputs with high } \\
\text { potential pollutants }\end{array}$ & $\begin{array}{l}\text { Coal is added direct- } \\
\text { ly to the reactor for } \\
\text { aeration, biological } \\
\text { oxidation and physical } \\
\text { adsorption occur si- } \\
\text { multaneously }\end{array}$ \\
\hline $\begin{array}{l}\text { Advanced Chemical Oxida- } \\
\text { tion }\end{array}$ & $\begin{array}{l}\text { It partially remove recalcitrant } \\
\text { organic material and refractory } \\
\text { compounds, dividing these } \\
\text { molecules with high molecular } \\
\text { weight, making them suscepti- } \\
\text { ble to microorganisms in bio- } \\
\text { logical reactors, increasing their } \\
\text { biotratability }\end{array}$ & $\begin{array}{l}\text { High process costs, such as energy, } \\
\text { the value of inputs demanded in } \\
\text { high doses and due to the com- } \\
\text { plexity of the operation, requires a } \\
\text { qualified technical operator }\end{array}$ & $\begin{array}{l}\text { Among oxidative tech- } \\
\text { nologies, ozonization is } \\
\text { the most widespread }\end{array}$ \\
\hline Evaporation C & $\begin{array}{l}\text { Leachate volume reduction up } \\
\text { to } 95 \%\end{array}$ & $\begin{array}{l}\text { Emission of polluted gases, high } \\
\text { energy cost where approximately } \\
60 \mathrm{~kg} \text { of gasoline is needed to burn } \\
1 \mathrm{~m}^{3} \text { of leachate. A dry sludge } \\
\text { output is generated in the order of } \\
5 \% \text { of the total volume }\end{array}$ & $\begin{array}{l}\text { The most widely used } \\
\text { option is the capture } \\
\text { and burning of the } \\
\text { biogas generated by } \\
\text { the landfill itself }\end{array}$ \\
\hline
\end{tabular}

Source: Compilations of fonts adapted from (BIDONE, 2007; LOBLICH, 2005; CRISTINA, 2002; RENOU et al., 2008; ROCHA, 2003; DIAS, 2017; NASCENTES, 2013; JAMALY et al., 2014)

\subsubsection{Co-treatment with domestic sewage}

The combined treatment of leachate with sanitary effluent in Sewage Treatment Plants (STP) is widely diffused in Brazil and worldwide. An important and current point of discussion inside the scientific community is the feasibility of co-treatment and what would be the ideal proportion of leachate / sewage in order to not harm the station and compromise the final effluent quality (SANTOS, 2009).

In Brazil, there is no specific legislation for co-treatment (MANNARINO et al., 2011). However, in the State of Rio de Janeiro (RJ), there is bill number 1857/2016 that mentions in its article 13 the prohibition of co-treatment in conventional STP at the State. Table 3 presents the conclusions of some co-treatment studies. 
Table 3 - Conclusions about co-treatment of domestic sewage leachate

\begin{tabular}{|c|c|c|c|}
\hline Study & Scale & Conclusions & References \\
\hline $\begin{array}{l}\text { Activated sludge and } \\
\text { activated sludge with } \\
\text { prolonged aeration }\end{array}$ & Laboratory & $\begin{array}{l}\text { It feasibility was achieved when they reached the RJ / } \\
\text { Brazil discharge standards for leachate / sewage rates } \\
\text { of up to } 3 \% \text { and } 2 \% \text {, respectively }\end{array}$ & NASCENTES (2013) \\
\hline $\begin{array}{l}\text { Anaerobic lagoons } \\
\text { followed by a facultative } \\
\text { and three of maturation }\end{array}$ & Real & $\begin{array}{l}\text { Leachate / sewage ratios of } 0.1 \text { to } 10.7 \% \text { were tested } \\
\text { with a mean of } 3.2 \% \text { for } 22 \text { months. It was found that } \\
\text { the concentrations of ammoniacal nitrogen inhibited } \\
\text { the action of algae in the lagoons. It was concluded } \\
\text { that the alternative was feasible especially in small } \\
\text { communities }\end{array}$ & BIDONE (2007) \\
\hline $\begin{array}{c}\text { Practical analyzes of } \\
\text { Brazilian STP }\end{array}$ & Real & $\begin{array}{l}\text { It is concluded that it is an environmentally and } \\
\text { economically safe methodology, especially for the } \\
\text { landfills and STP's that act in symbiosis, in which the } \\
\text { STP directs its sludge to the landfill and, in return, } \\
\text { the landfill leachate is disposed in the tributaries for } \\
\text { co- treatment }\end{array}$ & BOCCHIGLIERI (2010) \\
\hline $\begin{array}{l}\text { Activated Sludge and } \\
\text { Integrated Sludge Reactor } \\
\text { with Biofilm in Mobile } \\
\text { Bed }\end{array}$ & Pilot & $\begin{array}{l}\text { The two methodologies are feasible for up to } 20 \% \text { of } \\
\text { the leachate / sewage ratio, being able to stabilize the } \\
\text { recalcitrant substances and high levels of ammoniacal } \\
\text { nitrogen from leachate. The sludge generated in } \\
\text { the process does not present significant alteration } \\
\text { when compared to the unitary treatment of domestic } \\
\text { sewage, both in quantitative terms and in relation to } \\
\text { the present micro fauna }\end{array}$ & CAMPOS (2014) \\
\hline Batch activated sludge & Bench & $\begin{array}{l}\text { The most feasible mixing condition in the co- } \\
\text { treatment would be with pre-treated leachate, by an } \\
\text { aerobic oxygen injection process called Air Stripping, } \\
\text { in proportion of } 2 \% \text { leachate / sewage, increasing } \\
\text { efficiency } 10-20 \% \text { when compared to the mixture } \\
\text { made with pure leachate. In addition, the author states } \\
\text { that the proportion of } 5 \% \text { is technically unfeasible }\end{array}$ & $\begin{array}{c}\text { ALBUQUERQUE } \\
\text { (2012) }\end{array}$ \\
\hline $\begin{array}{l}\text { Aeration tank followed by } \\
\text { a decanter in continuous } \\
\text { flow }\end{array}$ & Laboratory & $\begin{array}{l}\text { The microbial fauna of the final effluent was } \\
\text { analyzed. It was verified that with the increase } \\
\text { of leachate concentration results in decrease of } \\
\text { biodiversity and microbiological activity. Therefore, } \\
\text { reestablishment of these factors after a few days. } \\
\text { It is concluded that despite the complexity of the } \\
\text { mixtures, the microorganisms were able to adapt. }\end{array}$ & $\begin{array}{l}\text { NASCENTES } \text { et al. } \\
\qquad(2015)\end{array}$ \\
\hline $\begin{array}{l}\text { UASB followed by an } \\
\text { aerated biological filter and } \\
\text { an anaerobic }\end{array}$ & Laboratory & $\begin{array}{l}\text { It was verified the viability for leachate / sewage } \\
\text { ratio of up to } 2.5 \% \text {, it was ratified by the author as a } \\
\text { promising technological prospection for STP's and } \\
\text { leachate treatment plants within landfills. }\end{array}$ & SANTOS (2009) \\
\hline $\begin{array}{l}\text { Activated sludge reactors } \\
\text { with } 20 \text { days batch regime } \\
\text { with pure leachate and pre- } \\
\text { treated by Air Stripping }\end{array}$ & Pilot & $\begin{array}{l}\text { It was concluded that the ideal leachate / sewage ratio } \\
\text { for the operation is } 2 \% \text {. However, the results were } \\
\text { not satisfactory and feasible in the removal of organic } \\
\text { matter and nitrogen }\end{array}$ & FERRAZ (2014) \\
\hline
\end{tabular}


After analyzing several studies, the authors uncovered some of the advantages and disadvantages of co-treatment, which are explained on Table 4.

Table 4 - Advantages and disadvantages of leachate co-treatment with domestic sewage

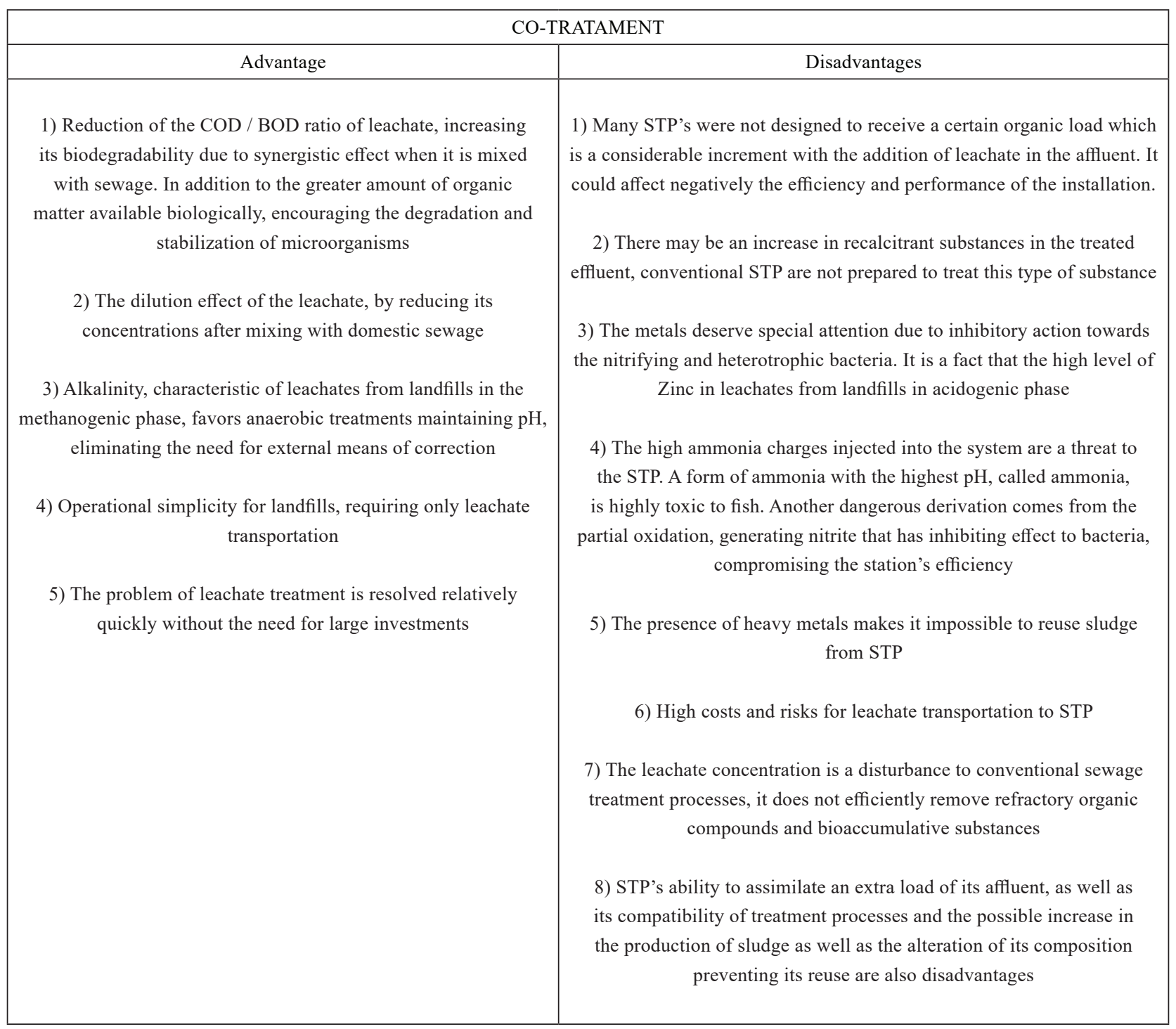

Source: Compilations of fonts adapted from (SANTOS, 2009; TEIXEIRA JÚNIOR; MARINHEIROS, 2014)

\subsubsection{Membrane Treatments}

With increasing legal restrictions and environmental controls on effluent discharge standards, conventional biological systems have proved to be inefficient in achieving the desired levels of removal. Therefore, the membrane processes arise to increase the quality of leachate treatment. It is being shown to be more efficient, adaptable and indispensable (RENOU et al., 2008).

The membrane systems are fed by leachate, pre-treated in some cases, for membrane preservation and energy savings by using lower pressures and, after the process, the permeate, effluent to be disposed, is produced. The process rejection is a liquid denominated concentrate. It is a highly polluting liquid that must have a proper destination and, in most cases, the concentrate has been recirculated at the own landfill. In general, membrane processes involve higher operational costs due to energy consumption, exchange and cleaning of membranes (HURD, 1999). However, the treatment units are more compact, have greater mobility and operational flexibility, as well as they are more effective and more operationally simple. Table 5 summarizes some advantages and disadvantages of each membrane technology 
Figure 3 - comparatively analyzes the filtration spectrum of the different types of effluent treatments by membranes

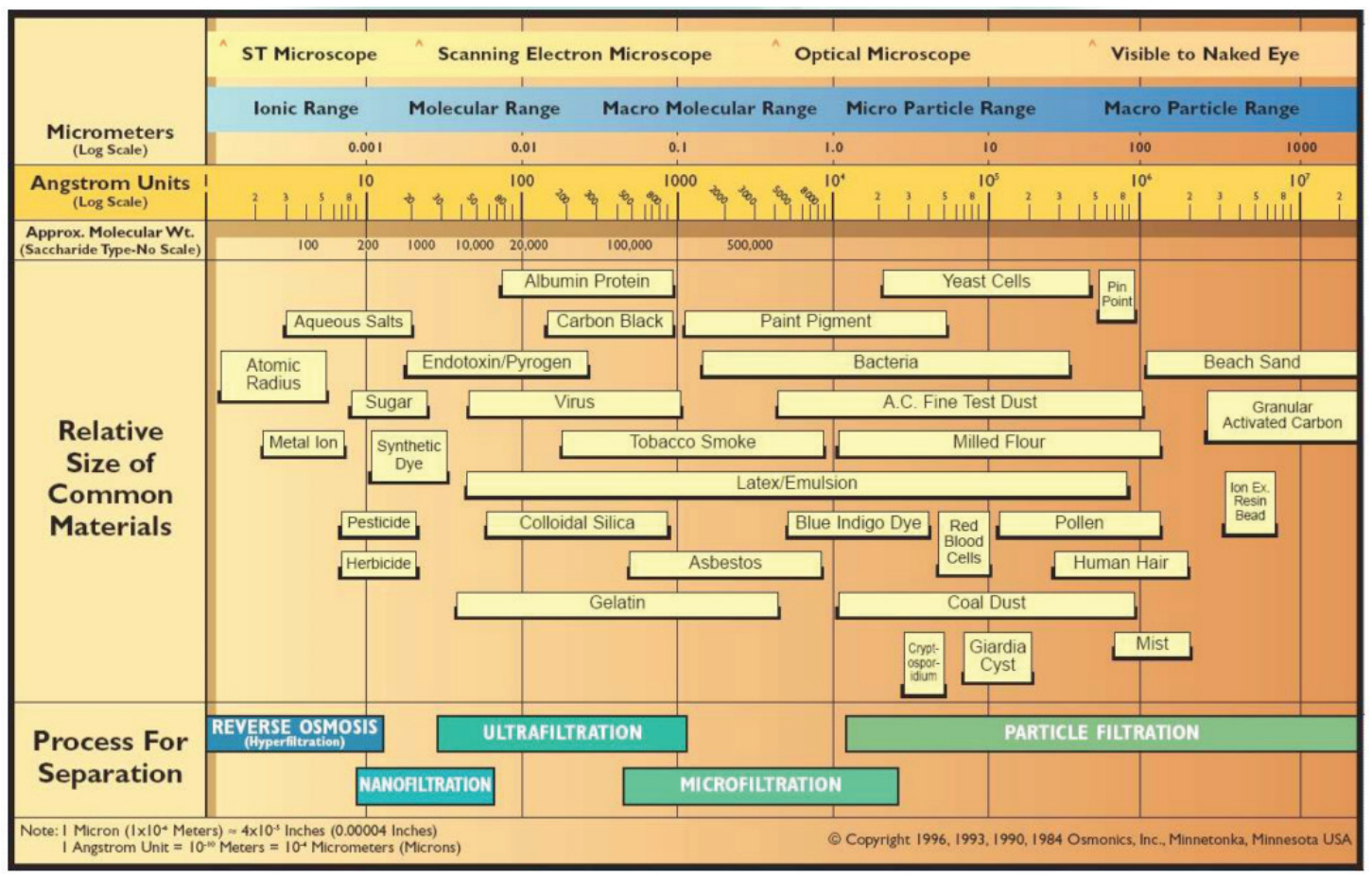

Source: Loblich, 2005

Table 5 - Advantages and disadvantages of membrane leachate treatments

\begin{tabular}{|c|c|c|c|}
\hline Membranes & Advantages & Disadvantages & Observations \\
\hline Ultrafiltration & $\begin{array}{l}\text { The organic matter can be removed with } \\
\text { an efficiency of } 50 \%\end{array}$ & $\begin{array}{l}\text { Does not have an efficient re- } \\
\text { moval of COD }\end{array}$ & $\begin{array}{c}\text { It is very used with Reverse Osmosis and } \\
\text { Membrane Bioreactor systems, reaching a } \\
\text { high level in the quality of leachate treat- } \\
\text { ment }\end{array}$ \\
\hline Nanofiltration & $\begin{array}{c}\text { Efficiency in COD removal, } 60-80 \%, 50 \% \\
\text { ammonia and control of organic, inorganic } \\
\text { contaminants, approaching the efficiency } \\
\text { of Reverse Osmosis }\end{array}$ & $\begin{array}{l}\text { For leachates with high calcium } \\
\text { concentrations, combined with } \\
\text { high levels of organic matter, } \\
\text { can cause excessive membranes } \\
\text { fouling, increasing operational } \\
\text { costs }\end{array}$ & $\begin{array}{l}\text { It becomes a problem when chlorides re- } \\
\text { moval is required by the current legislation, } \\
\text { being an efficient hybrid treatment, especial- } \\
\text { ly with biological systems }\end{array}$ \\
\hline $\begin{array}{l}\text { Reverse Os- } \\
\text { mosis }\end{array}$ & $\begin{array}{l}\text { Better efficiency in the removal of all pol- } \\
\text { lutants, between } 98 \text { to } 99 \% \text {. Operational } \\
\text { cost are competitive }\end{array}$ & $\begin{array}{l}\text { Energy costs are the highest } \\
\text { of membrane systems, about } 5 \\
\mathrm{kWh} / \mathrm{m}^{3} \text { due to high pressures }\end{array}$ & $\begin{array}{c}\text { It has been successfully applied in the last } 30 \\
\text { years throughout Europe }\end{array}$ \\
\hline $\begin{array}{l}\text { Membrane } \\
\text { Bioreactor } \\
\text { (MBR) }\end{array}$ & $\begin{array}{l}\text { Removals that reach } 99 \% \text { in BOD and } 70 \\
\text { to } 96 \% \text { of COD. Bacteria maintenance } \\
\text { inside the reactor, higher concentration } \\
\text { of biomass generated, compaction, op- } \\
\text { erational flexibility, automated control } \\
\text { of hydraulic detention time and sludge, } \\
\text { removal of up to } 95 \% \text { of recalcitrant sub- } \\
\text { stances and attends high volumetric loads }\end{array}$ & $\begin{array}{l}\text { Higher investment costs and } \\
\text { operational complexity }\end{array}$ & $\begin{array}{l}\text { The potential of using an MBR system up- } \\
\text { stream of a reverse osmosis unit for purifica- } \\
\text { tion is interesting in reducing the frequency } \\
\text { of downstream membrane fouling and } \\
\text { producing a very high quality effluent with } \\
\text { lower concentrate generation. Therefore, the } \\
\text { technological combination recently pointed } \\
\text { out as more efficient and effective }\end{array}$ \\
\hline
\end{tabular}

Source: Compilations of fonts adapted from CRISTINA, 2002; HURD, 1999; RENOU et al., 2008; PENG, 2013; NASCENTES, 2013; JAMALY et al., 2014) 


\section{Final Considerations}

It is observed the complexity and variability of leachate, as well as the diversity of treatment technologies. They are widely debated both theoretically and experimentally, through practical analysis in leachate treatment plants in operation. All technologies have advantages and disadvantages in terms of efficiency, effectiveness, economy, operational feasibility and logistics, and it is a challenge to choose the most appropriate for a specific situation. Because of this, it is extremely important a depth analysis of each scenario in which a leachate treatment plant is being planned, in order to obtain a satisfactory treatment operation for shareholders.

The co-treatment of leachate with domestic sewage has several studies that evaluate different aspects. However, it is still surrounded by questions and uncertainties about its results and operational consequences in the medium and long term on real scale situations. Another important aspect is the environmental control parameters of the final effluent quality in STP, where ecotoxicological effects are not yet defined, besides the uncertainties regarding the effect of the recalcitrant substances in the processes. The possible contamination of sludge is also a disadvantage that may restrict its reuse. The high volumes of leachate transport from landfills to the STP's are costly and risky. However, this solution has a more immediate result, when there is still no local treatment of leachate, and this is accumulated in storage ponds, with significant costs, especially in area, and risky because of possible leaks by extrapolation, caused by lack of planning and/or periods of unexpected heavy rains.

Therefore, the importance of in situ treatment occurs due to high cost and risk during leachates transport. The National Sanitation Information System (SNIS) provides knowledge about waste management in Brazilian municipalities. The system can clarify the leachate treatment panorama in Brazil, with information provided by the bodies responsible for its management. The most recent study refers to the year 2016, and this investigation shows that $15 \%$ of municipalities have internal facilities for leachate treatment, Figure 4, while 8\% have external facilities, Figure 55 (LEY et al., 2018).

Figure 4 - Number of units that have internal treatment of leachate

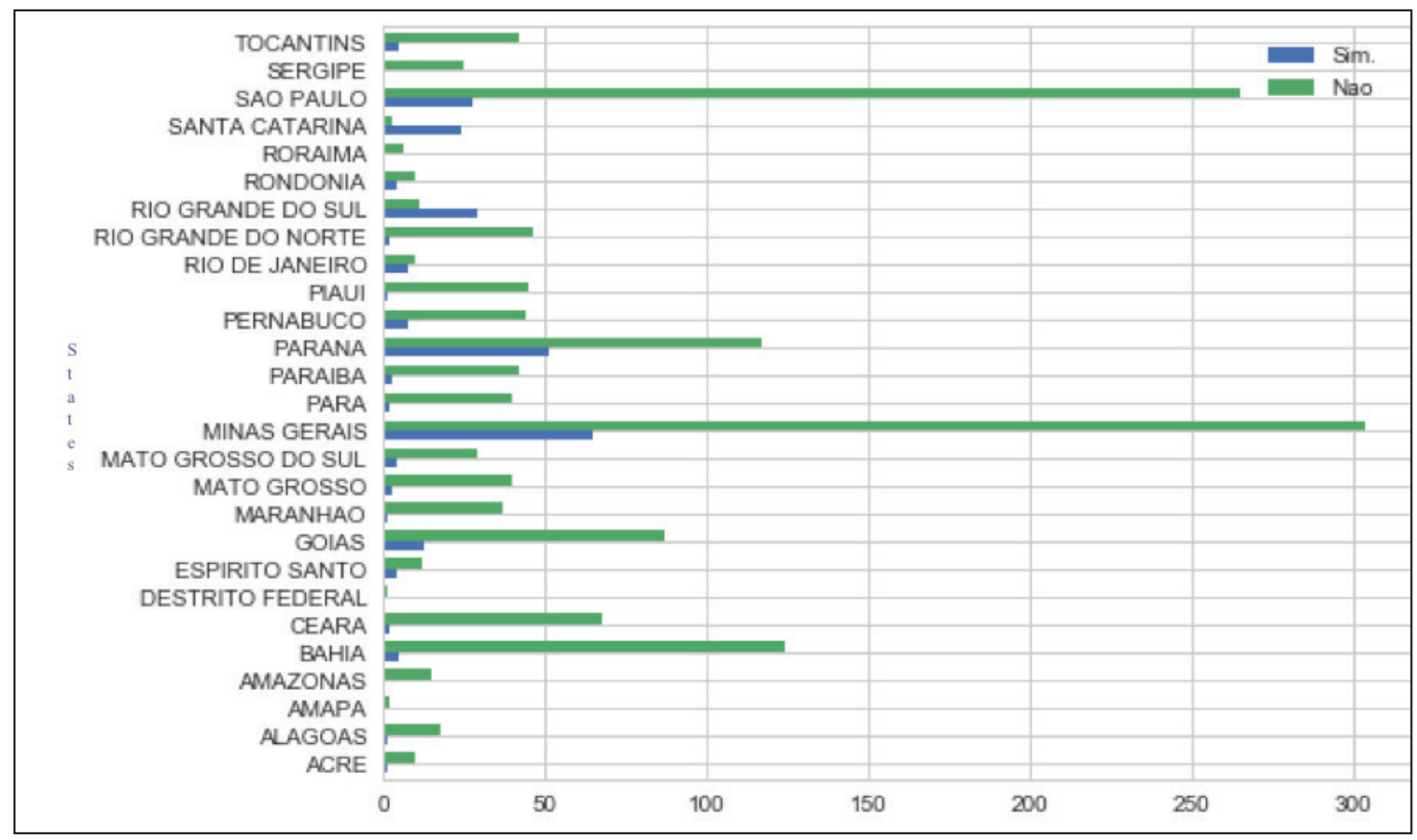

Source: Ley et al., 2018 
Figure 5 - Quantity of units that have external treatment of leachate

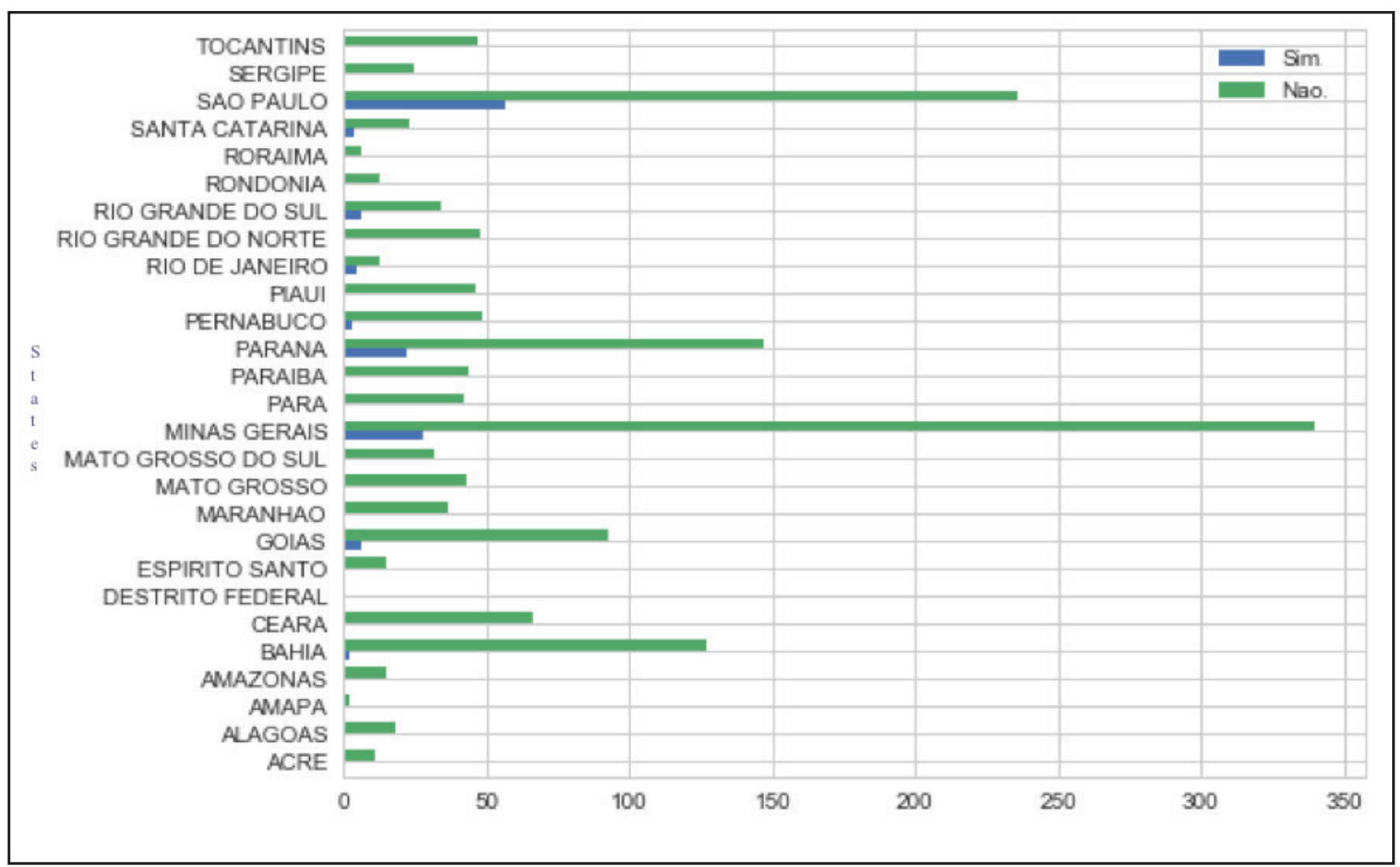

Source: Ley et al., 2018

Thus, from this data set it is possible to extract that the states of Santa Catarina and Rio Grande do Sul have a higher percentage of units with internal treatment, with $89 \%$ and $73 \%$, respectively. In terms of external treatment, Rio de Janeiro's largest representative was Rio de Janeiro, with $28 \%$ of its facilities (LEY et al., 2018).

\section{Conclusions}

It is concluded that the correct treatment of leachate is one of the greatest challenges for landfill operators. In fact, leachate configures a threat to the water security of countries, with short, medium and long-term impacts, covering fauna, flora, atmosphere, soil and constitutes a negative externality for the whole society.

Among the treatment processes, those using membranes are more efficient because their essence of physical separation of the undesirable components of leachate maintains an operational and logistic safety while the chemical and biological treatment processes can be affected slowly by the variability of the physicochemical composition of leachate at the own landfill. Moreover, chemical treatments require considerable input volumes, resulting in logistic consequences and constant technical qualification for operation, hampering the operational procedures of routine and the technicians responsible for the leachate treatment plant.

Furthermore, membrane treatment technology is a viable and efficient alternative, it is being approval world spread specially first world countries. The generated permeate can meet the discharge requirements of the environmental organs, due to its high pollutant removal rates and can be reused. The technologies have a maturity and constant development, being periodically improved by reductions of operational costs, especially through the technological development of membranes. It should be emphasized that the production of concentrate (residue from membrane processes) is still a challenge for these technologies, since in most cases the solution still used is the recirculation at the own landfill, studies are also trying to improve destination and treatment of concentrate.

In the end, it is notable that there are still several studies to be realized in order to increase the certainties of different optics and particularities of this subject. It is recommended that there be practical and depth studies which analyses the operation of STP's with different co-treatment methods in ecotoxicological quality of the final effluent, the operational consequences at 
the station in a short, medium and long term, covering environmental, economic, logistic and technical aspects. An area still possible to be explored are more studies related to the reduction or treatment of membranes concentrate.

\section{References}

ABRELPE. 2017 Overview of solid waste in Brazil. Brazilian Association of Public Cleaning and Special Waste Companies, 2018, p. 74.

ALBUQUERQUE, E. M. de. Evaluation of the combined treatment of landfill leachate and sanitary sewage in activated sludge system. São Carlos: University of São Paulo, 2012.

BIDONE, R. F. System composed of anaerobic filters followed by constructed batts: a case study - Central de Resíduos do Recreio, in Minas do Leão / RS. São Carlos: University of São Paulo, 2007.

BOCCHIGLIERI, M. M. Leachate from sanitary landfills in treatment plants of public sewage systems. São Paulo: University of São Paulo, 2010.

CAMPOS, F. Influence of the Receipt of Landfill Leachate on the Treatment of Sewage in Process of Activated Sludge and Integrated Reactor of Activated Sludge with Biofilm in Mobile Bed. São Paulo: University of São Paulo, 2014.

COSTA, T. J. S. da. Treatment of leachate from sanitary landfills of urban solid waste in Portugal. Lisbon: Technical Lisbon, 2015.

CRISTINA, A. Treatment of Landfill's leachate and toxic evaluation of affluent and effluent. Federal University of Rio de Janeiro, 2002.

DI MARIA, F.; SISANI, F. A life cycle assessment of conventional technologies for landfill leachate treatment. Environmental Technology \& Innovation, v. 8, 2017, p. 411-422.

DIAS, A. C. Activated sludge with activated carbon addition in co-treatment of domestic sewage and leachate from landfill. Rural Federal University of Rio de Janeiro o, 2017.

FERRAZ, F. de M. Treatable leachate study of sanitary landfills - emphasis on the treatment consortium with sanitary sewage in aerobic systems. São Carlos: University of São Paulo, 2014.

FERRAZ, F. M.; BRUNI, A. T.; POVINELLI, J.; VIEIRA, E. M. Leachate / domestic wastewater aerobics co-treatment: a pilot-scale study using multivariate analysis. Journal of Environmental Management, v. 166, 2016, p. 414-419.

FRANCO, H. A.; SILVA, M. E. R. V. da; SILVEIRA, M. F. da; MARQUES, M. R. da C.; THODE FILHO, S. Impact of landfill leachate on the germination of Cucumber (Cucumis sativus). Electronic Magazine in Environmental Management, Education and Technology Santa Maria, v. 21, 2017, p. 32-44.

HURD, S. Low-Pressure Reverse Osmosis Membrane Treatment of Landfill Leachate. Ottawa: University of Ottawa, 1999.

JAMALY, S. et al. A short review on reverse osmosis pretreatment technologies. Desalination, v. 354, p. 30-38, 2014

KAMARUDDIN, M.A.; YUSOFF, M. S.; RUI, L. M.; ISA, A. M.; ZAWAWI, M. H.; ALROZI, R. An overview of municipal solid waste management and landfill leachate treatment: Malaysia and Asian perspectives. Environmental science and pollution research international, v. 24, n. 35, 2017, p. 26988-27020.

LEY, M. B. R. G.; LIPPI, M.; NASCENTES, A. L. Analysis of SNIS data on solid waste using Python language. In: 18o ENASB/18o SILUBESA. Porto, 2018.

LOBLICH, S. Slurry Treatment Systems - solutions for direct discharge in the water medium. In: 5th International Technical Days of Waste. Funchal, 2005. 
MANNARINO, C. F.; FERREIRA, J. A.; MOREIRA, J. C. Combined treatment of leachate from landfills of urban solid waste and domestic sewage as an alternative for the solution of a serious environmental and public health problem - bibliographic review. Collective Health Notebook, v. 19, n. 1, 2011, p 11-19.

NASCENTES, A. L. Anaerobic conjugate treatment of landfill leachate and domestic sewage. Rio de Janeiro: Federal University of Rio de Janeiro, 2013.

NASCENTES, A. L.; NASCIMENTO, M. M. P. DO; BRASIL, F. da C.; CAMPOS, J.C.; FERREIRA, J.A. Combined treatment of landfill leachate and domestic sewage - operational and microbiological aspects. Electronic Review Teccen, v. 8, 2015, p. 05-12.

PENG, Y. Perspectives on technology for landfill leachate treatment. Arabian Journal of Chemistry, v. 10, 2013, p. S2567-S2574.

RAGAZZI, M. Sewage and Landfill Leachate - Assessment and Remediation of Environmental Hazards. Oakville, ON: Apple Academic Press, 2016, p. 296.

RENOU, S.; GIVAUDAN, J.G.; POULAIN, S.; DIRASSOUYAN, F.; MOULIN, P. Landfill leachate treatment: Review and opportunity. Journal of Hazardous Materials, v. 150, n. 3, 2008, p. 468-493.

ROCHA, C. A. M. Membrane Bioreactor and Reverse Osmosis in Landfill's Leachate Treatment. Faculty of engineering of Porto University, 2003.

SANTOS, A. F. D. M. S. Anaerobic treatment of slurry in conjunction with sanitary sewage. Recife-PE: Federal University of Pernambuco, 2009.

SANTOS, M. P. A; NASCENTES, A. L, JUNIOR, A. B. C.; TAVES, R. F.; Leachate treatment from landfill: A bibliometric analysis. First South American Congress of Solid Waste and Sustainability, 2018.

SHAH, T. M.; RAMASWAMI, S.; BEHRENDT, J.; OTTERPOHL, R. Simultaneous removal of organics and ammoniumnitrogen from reverse osmosis concentrate of mature landfill leachate. Journal of Water Process Engineering, v. 19, 2017, p. 126-132.

TALALAJ, I. A. Removal of organic and inorganic compounds from landfill leachate using reverse osmosis. International Journal of Environmental Science and Technology, v. 12, n. 9, 2015, p. 2791-2800.

TEIXEIRA JÚNIOR, W. P.; MARINHEIROS, L. M. Landfills's leachate treatment in conventional sewage tretament plants: Critical analyses. Ambiente Legal Magazine produced by Environmental Corporate Intelligence Agency (AICA) , 2014. 